本邦において 2004 年の膵癌の死亡数は 22,260 人であり男性 11,933 人, 女性 10,327 人であり, 男 女とも第 5 位を占めている ${ }^{1,2)}$. 米国でも年間 33,000 人以上の膵癌患者が亡くなっている. 15〜 $20 \%$ の膵癌患者が根治可能ということで手術が なされているが, 残りの大半は局所で進行してい るかあるいは転移していると考えられる．生存期 間中央值は局所進行癌では 8-12 カ月, 転移癌では 3-6 カ月といわれており他の癌に比較して非常に 悪い. 何故, 膵癌は他の癌と異なり, このように 進行した状態でしか発見されないのか. ひとつは 膵癌はほとんどが脺管癌であり, その症状が非常 に出にくいと思われる，その為に診断が遅れるわ けである，また，膵癌の中で部位によっても症状 が異なる，膵頭部癌であれば, 黄疸で発症するこ とが多いが, 膵尾部癌では殆んど症状がなく, 膵 頭部癌と比較しても診断が遅れる傾向がある. 次 の原因としては小膵癌を診断する為の特異的な modality がやはり少ないということがいえる. 小 膵癌は膵管から発生するので, 腫瘤を形成するに はかなり時間がかかることと造影効果の少ない腫 瘍なので, 従来の腹部超音波や腹部 CT ではかな り発見しにくいと思われる. 最後に膵癌は他の癌 と異なり, 浸潤傾向の非常に高い癌（特に神経浸 潤）であることが挙げられる。これにより進行し た癌の形で認められることが多い.

脺癌治療の基本は進行度によって手術, 全身化 学療法, 放射線療法あるいはこの組み合わせで行 われる. 病期により治療方針が決定される. 因み に stage I は癌の大きさが $2 \mathrm{~cm}$ 以下で膵臓の内部 に限局した状態であり, stage II は癌の大きさが 2 $\mathrm{cm}$ を越えているが, 膵臓の内部に限局した癌ま

\footnotetext{
* 東海大学医学部内科学系消化器内科学
}

たは癌の大きさ $2 \mathrm{~cm}$ 以下で 1 群のリンパ節に転 移のある場合であり, stage III は癌の大きさに関 係なく, 癌が膵外に出ているがリンパ節転移が第 1 群にとどまる癌であり, 癌が膵臓の内部にとど まっているかリンパ節転移が第 2 群まである癌で ある. Stage IV は主に膵臓の周辺の血管, 神経を まき込んでいる癌 (IVa)または主に離れたリンパ 節, 臓器に転移がある場合 $(\mathrm{IVb})$ である。この中 で手術を第 1 選択にするものは第 III 期までで, 第 IVa 期で大きな血管に浸潤を認めず, 転移があ まりなければ膵癌取扱い規約第 4 版の S2 または RP2 または PV2,かつ N0 またはN N1 が手術の対 象となる. 膵切除率は 1981 年に $24.9 \%$ であった が 2000 年には $42.6 \%$ と上昇したが未だに切除例 の 1 年生存率は $52.7 \%, 3$ 年生存率は $24.0 \%, 5$ 年生存率は $18.2 \%$ である ${ }^{3)}$.

Stage IVa期手術の適応がない症例や stage IVb 期には化学療法や放射線療法が行われること になっている.では, 膵癌はどの stage で多く発見 されているかというと殆んどが stage IV 期であ るといえる. そこでこれらの stage IV 期で手術が できない症例をどうするかということになる.

Fig. 1 はICC (国際対がん連合)の各分類毎の 累積生存率を示しているが stage III および stage IV の予後は極めて不良である $\left(\mathrm{UICC}^{4)}\right.$ と日本膵藏 学会5)の stage 分類は多少異なるが)。 そこでこれ らの stage IV 期のうち手術の対象とならない症 例をどうするかということになる.

2001 年塩酸ゲムシタビン $(\mathrm{GEM})$ が膵癌治療の 適応薬として認められて以来, 現在化学療法とし て筆頭に挙げられるのが GEM である（2006 年 8 月にはテガフール・ギメラシル・オテラシルカ リウム（TS-1）が膵癌治療の適応薬として認めら 


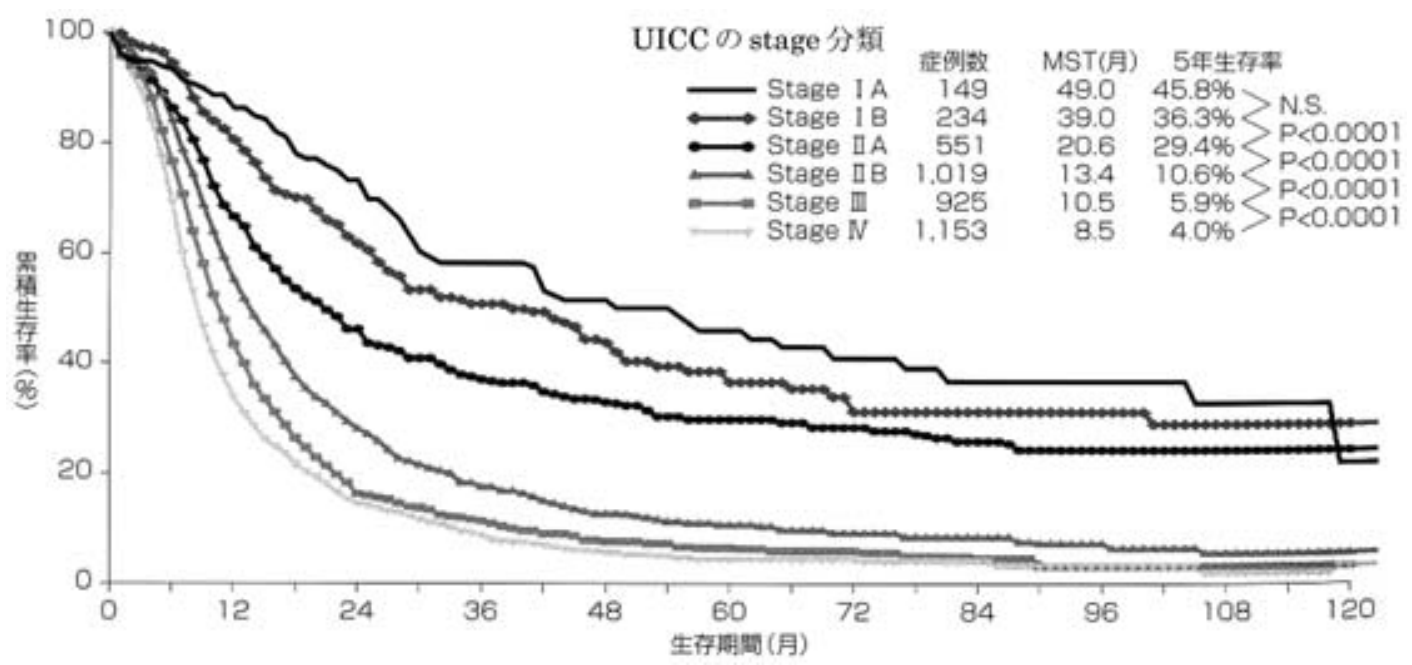

Fig. 1 膵頭部通常型膵癌切除例 UICC-Stage（第6 版）と予後 2,10)

れた).この薬剤は画像での評価は明らかな改善を 生じないことが多いが, しかし症状緩和効果 (CBR : Clinical benefit response) として, 症状 （痛み，体重減少）やPS (Performance status)を 改善させる．実際に症状緩和効果は高く，27\%く らいである。抗腫瘍効果(腫瘍を縮小する効果) は これと比較して低く $11 \%$ とされている. 現在, GEM は遠隔転移を有する進行膵癌に対する第一 選択薬と考えられている. 従来の標準的治療薬で あったフルオロウラシル (5-FU) と比較して GEM 群が臨床的に優れたものであったことから，

NCCN (National Comprehensive Cancer Network : 全米総合がん情報ネットワーク)のガイド ライン ${ }^{6}$ において 5-FU は転移再発例の救済療法 のみにカテゴリー $2 \mathrm{~B}$ として記載されている。本 邦でも 2004 年に抗癌剤適正使用ガイドライン「膵 がん」が公表され切除不能膵癌に対する項で「進 行膵がんの第一選択薬剤はゲムシタビンである」 と記載されている7). 膵癌診療ガイドラインでは 遠隔転移後の膵癌例については第一選択となって いる ${ }^{1)}$ 5-FUについては抗腫瘍効果は 0 67\% とされているが, 残念ながら 5-FU とホリナート カルシウムとの併用したデータは特に悪く, 0 $9 \%$ とされている ${ }^{8}$. 生存期間中央值が 10〜24 週 とされているカペシタビンは腸管から吸収され
て, thymidine phosphorylase で 5-FUに変換され る抗癌剤である。カペシタビンは $7 \%$ しか抗腫痬 効果はないが症状緩和効果は $24 \%$ あった ${ }^{9)}$. 前述 したように 5-FU と GEM の比較試験では症状緩 和効果は GEM が $24 \%$ であり $5-\mathrm{FU}$ が $5 \%$ で あった. 1 年生存率も GEM が $18 \%$ であり $5-\mathrm{FU}$ が $2 \%$ であった. Fig. 2 は GEM と 5-FU との比較 試験であるが GEM の方が明らかに有効であっ た ${ }^{10)}$. GEM はシタラビンと類似の構造を有して おり, 細胞内で deoxycytidine kinase により塩酸 ゲムシタビン-3リン酸という活性型になって作 用するが $10 \mathrm{mg} / \mathrm{m}^{2} / \mathrm{min}$ の投与量で酵素活性が飽 和することもあり，長時間の投与，高濃度の短時 間投与も検討されている。 しかし，投与法により それ以上の効果を示した報告はない。これらの報 告より GEM の濃度をあげても効果と関係がな く，寧ろ副作用との関係があるとされている.

アンソラサイクリン，ストレプトゾトシン， イ フォスファマイドはあまり効果なくタキサンもあ まり効果がない. 複数の抗癌剤のコンビネーショ ンがかなり行われている.

GEM とのコンビネーションでは 5-FU との併 用療法は GEM 単独の効果を越えなかった. カぺ シタビンとのコンビネーションも GEM を越えな かった. シスプラチンも GEM とは相乗効果があ 

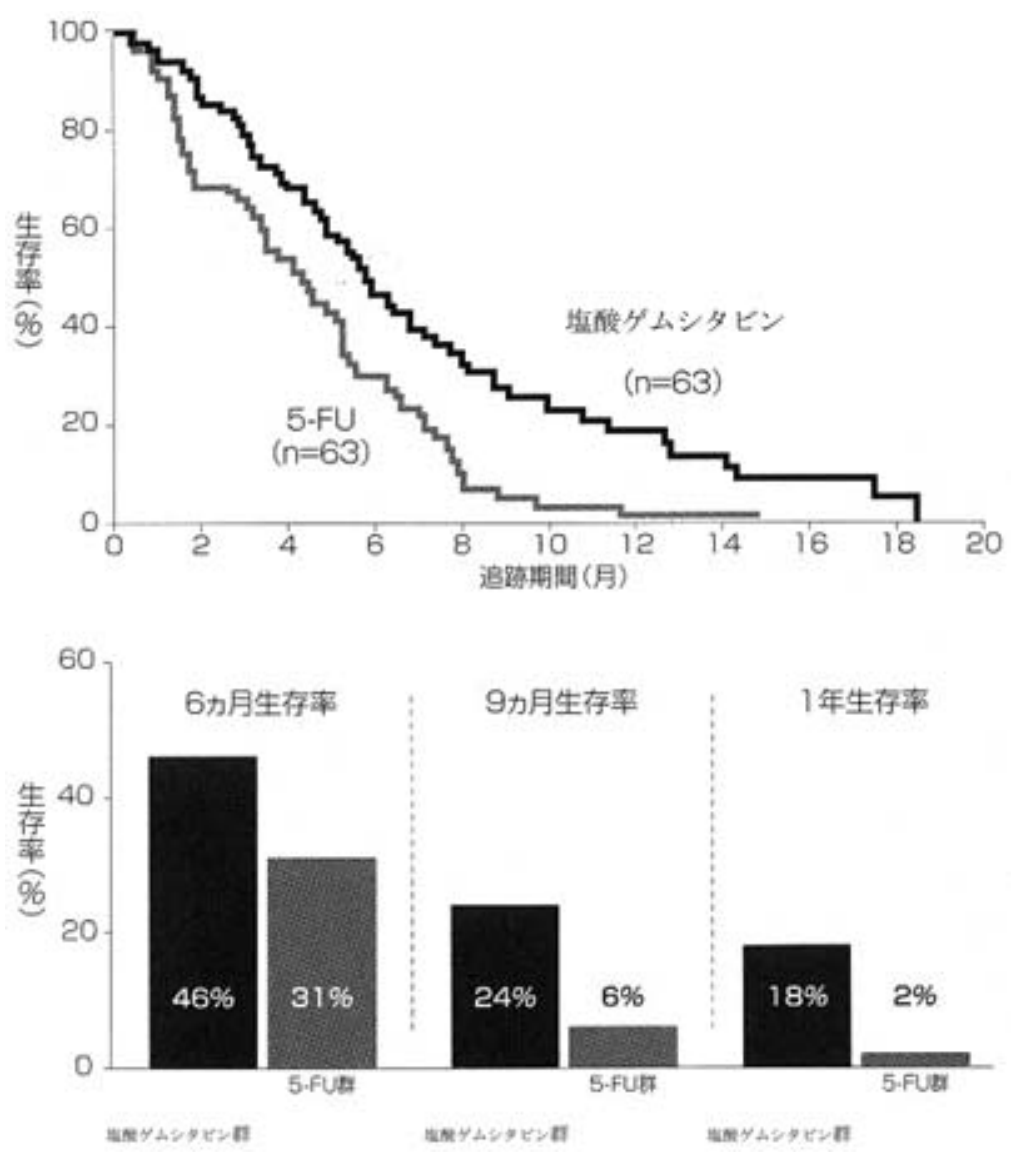

Fig. 2 進行膵癌患者に対する塩酸ゲムシタビンと 5-FU 比較試験 ${ }^{10)}$

ると予測されていたが, GEM とシスプラチンの 併用療法は GEM の単独効果を越えなかった。最 終的には 2006 年の Cochrane の review でも ${ }^{12)} 16$ 種類の無作為の試験が行われたが，殆んど GEM の効果を上回ることができなかった．5-FUにつ いてもドキソルビシンなどとの併用療法は $5-\mathrm{FU}$ を越えるものはなかった．セカンドラインについ ては GEM に耐性のものはセカンドラインに変更 しても必ずしも効果はないが $5-F U$ も oxaliplatin に変更しても必ずしもいい効果を示さない. 更に Ras 蛋白を不活性化する薬や matrix metalloproteinase inhibilior も効果は殆んどなかった. 現在, EGF 受容体や VEGF 受容体のチロシンキナーゼ に対する治療効果が検討されている. 本雑誌には これらをふまえた膵癌化学療法の現状が述べられ
ており，一部には今後の抗癌剤の投与法（ネオア ジュバント）についても検討した. また，このパ ネルディスカッションを企画してくださった第 37 回日本膵蔵学会の杏林大学の跡見会長, および この機会を与えていただいた東北大学の下瀬川徹 教授には心から感謝を申し上げたい.

\section{文献}

1) 日本膵臟学会膵癌診療ガイドライン作成小委員会編. 膵癌診療ガイドライン 2006 年度版. 東京 : 金原出版 株式会社, $2006: 55$.

2) 日本膵臓学会膵癌登録. 膵臓 $2003 ; 18: 101-69$.

3）吉田雅博, 他 : 膵癌の外科的治療と成績: 欧米との比 較一膵癌治療成績向上のための拡大手術と合理的手 術. 内科 $2000 ; 86: 912-8$.

4) UICC 国際対がん連合. Sobin LH, Wittekind H 編. TNM 悪性腫瘍の分類 第 6 版. $2002: 95-8$. 
5）日本膵臓学会編. 膵癌取扱い規約 第 5 版. 東京：金 原出版株式会社, 2002：3-11.

6) NCCN (National Comprehensive Cancer Network) Clinical Practice Guideline in Oncology, Pancreatic Adenocarcinoma Version 1 2002. (http://www.nccn. org/physirian-gls/f-guideline.ht.ml)

7）抗がん剂適正使用ガイドライン 膵癌. Int Clin Oncol 2004 ; 9 (Suppl II) : 15-9.

8) Crown J, Casper ES, Botet J, Murray P, Kelsen DP. Lack of efficacy of high-dose leucovorin and fluorouracil in patients with advanced pancreatic adenocarcinoma. J Clin Oncol $1991 ; 9$ : 1682-6.

9) Cartwright TH, Cohn A, Varkey JA, et al. Phase II study of oral capecitabine in patients with advanced or metastatic pancreatic cancer. J Clin Oncol 2002 ;
$20: 160-4$.

10) Burris HAIII, Moore MJ, Andersen J, et al. Improvements in survival and clinical benefit with gemcitabine as first-line therapy for patients with advanced pancreas cancer : a randomized trial. J Clin Oncol $1997 ; 15: 2403-13$.

11) Grunewald R, Kantarjian H, Keating MJ, Abbruzzese J, Tarassoff P, Plunkett W. Pharmacologically directed design of the dose rate and schedule of 2', 2'-difluorodeoxycytidine administration in leukemia. Cancer Res $1990 ; 50: 6823-6$.

12) Yip D, Karapetis C, Strickland A, Steer CB, Goldstein D. Chemotherapy and radiotherapy for inoperable advanced pancreatic cancer. Cochrane Database Syst Rev $2006 ; 3:$ CD002093.

\title{
Recent advances in chemotherapy for pancreatic carcinoma
}

\author{
Tetsuya MinE*
}

Key words : Pancreatic carcinoma, Chemotherapy, Advances, Gemcitabine, TS-1

The treatments for pancreatic carcinoma seem to be inadequate compared with other malignancies even at present, the rate of resectability is low compared with other malignancies. Therefore, the role of chemotherapy is important especially for inoperable patients with pancreatic carcinoma. The first line of chemotherapy for pancreatic carcinoma is gemcitabine, which has been approved for use. This year, TS -1 was also approved as one of the anticancer drugs for pancreatic carcinoma. In this manuscript, the present status of anticancer drugs for pancreatic carcinoma including trials of combination therapy of anticancer drugs is discussed.

* Division of Gastroenterology and Hepatology, Department of Internal Medicine, University of Tokai School of Medicine (Isehara) 